\title{
DIE DINGLICHE RECHTSLAGE DES ERLÖSES AUS DER VERSTEIGERUNG VERPFÄNDETER UND GEPFÄNDETER SACHEN.
}

VON

DR. IUR. RUDOLF MARTIN POLLACK

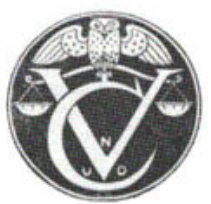

LEIPZIG

VERLAG VON VEIT \& COMP.

1915 
Leipziger juristische Inauguraldissertation. 